\title{
Nature of environmental variability experienced by benthic and pelagic animals in the St. Lawrence Estuary, Canada*
}

\author{
Réjean Laprise $^{* *}$, Julian J. Dodson*** \\ Département de Biologie, Université Laval, Sainte-Foy, Québec, Canada G1K 7P4
}

\begin{abstract}
We compared the short-term variability in salinity, temperature and concentration of suspended particulate matter experienced by benthic and pelagic animals in the middle St. Lawrence Estuary on both horizontal and vertical axes. In addition, we examined the effect of 3 patterns of vertical distribution (no vertical migrations, diel and tidal vertical migrations) on the environmental variability experienced by pelagic animals. Results demonstrated that the nature of environmental variability is different for the 2 types of animal. For benthic animals, environmental variability is experienced on the horizontal axis, whereas the vertical axis is more important for pelagic animals. The magnitude and frequency of abiotic fluctuations experienced by benthic animals depend on the environmental factors that control the longitudinal position of the estuarine gradient, whereas for pelagic animals they mostly depend on the animals' behaviour on the vertical axis. Consequently, favourable habitats for benthic and pelagic animals in the estuary are different. The most upstream section of the estuary is the most variable for benthic animals because the tides of greatest range generate the highest abiotic fluctuations on the horizontal axis. In contrast, the same section is the most abiotically stable for pelagic animals because tides of highest energy generate the strongest vertical mixing. The highest abiotic fluctuations experienced by these animals are in the most vertically stratified waters downstream in the estuary. As a result, minimum numbers of species of benthic and pelagic animais are reached at different locations in the estuary corresponding to the areas which are the most abiotically variable for each type of animal. We propose that well-mixed parts of estuaries should be considered as abiotically stable habitats for the pelagic fauna, whereas vertically stratified areas should be considered as abiotically variable except in the case where vertical migrations are not necessary for the retention of animals.
\end{abstract}

\section{INTRODUCTION}

Estuaries are characterized by the presence of a longitudinal gradient in salinity with which other gradients in physico-chemical parameters, such as temperature and concentration of suspended particulate matter, are associated (Pritchard 1967). In drowned-river-valley estuaries, these environmental parameters may fluctuate at any point in the estuary

\footnotetext{
- Contribution to the programme of GIROQ (Groupe Interuniversitaire de Recherches Océanographiques du Québec)

- Present address: Department of Fisheries and Oceans, Northwest Atlantic Fisheries Center, PO Box 5667, St. John's, Newfoundland, Canada A.1C 5X1

-..Addressee for reprint requests
}

according to displacements of the longitudinal gradient induced by factors such as tides and river discharge (Bassindale 1943). These fluctuations in abiotic conditions may cause major physiological problems for animals (Parry 1966, Green 1968, Holliday 1971, Kinne 1971, Remane \& Schlieper 1971, Beadle 1972, Vernberg \& Vernberg 1972). Studies on salinity and temperature demonstrated that fluctuations may have major effects on locomotion, growth, reproduction and ultimately survival because osmotic and thermic stresses cause changes in basal metabolic rate, which reduces surplus energy available for other activities. These observations have led to the widely accepted concept that estuarine ecosystems are variable (or unstable) environments. This concept has played a fundamental role in estuarine ecology and constitutes 
one of the principal assumptions of several hypotheses that explain a whole range of observations. For example, fluctuations in salinity may constitute a major factor controlling the distribution of estuarine animals (e.g. Heerebout 1970, De Jonge 1974). Burrowing in the sediment may be an adaptation reducing tidal salinity fluctuations (e.g. McLusky 1968). Environmental variability may be responsible for the lower diversity of estuarine organisms compared to marine and limnic environments, few species being adapted to tolerate rapid changes in abiotic conditions (Green 1968, Sanders 1969, Kinne 1971, McLusky 1981, Haedrich 1982, Miller et al. 1985). Estuarine communities may be mainly 'physically controlled' in opposition to the 'biologically accomodated' communities found in areas where physical conditions are constant and uniform for long periods of time (Sanders 1969, McLusky 1981). All these hypotheses and others assume that estuarine animals are subjected to fluctuations in environmental conditions.

The mechanism that generates environmental variability for animals in estuaries may be reduced to 2 components. The first component corresponds to the presence of longitudinal and vertical gradients in physico-chemical parameters. The second component is dynamic: environmental variability results from the movement of animals against the spatial gradients. The speed and direction of this movement determine the rate and the direction of changes in abiotic conditions an individual experiences.

Most of the information available on the nature of environmental variability experienced by estuarine animals comes from studies of benthic organisms. For these animals, the periodic longitudinal displacement of the horizontal gradient caused by tides and seasonal fluctuations in river discharge generates most of the variability in physico-chemical conditions. Sessile animals are exposed to the whole range of fluctuations observed at one geographic point in the estuary, unless adaptations such as living in interstitial waters or in a shell reduce the range of fluctuations experienced by an individual (Kinne 1971).

However, knowledge about benthic fauna is not always relevant for animals living in the water column. For example, pelagic animals are transported by tidal currents and move upstream and downstream according to the displacement of water masses (e.g. Gagnon \& Lacroix 1981, 1982, Laprise \& Dodson 1989a, b, 1990). As a result, tidal variability should be lower for pelagic animals than for benthic animals, because they should not move with respect to the environmental gradient but rather remain in the same body of water for some period of time. On the other hand, several pelagic animals undertake vertical migrations in the water column. This dimension, not present for benthic animals, may be an important source of environmental variability. First, vertical migrations in current shears may modify the position of animals along the environmental gradient (Miller 1970). Second, fluctuations in abiotic conditions will be experienced if migrations occur in vertically stratified waters. However, there are no data in the literature that document the abiotic variability experienced by pelagic animais in estuaries, nor is there a clear distinction in general accounts of how environmental factors that create abiotic variability may have different effects on benthic and pelagic animals.

The purpose of this paper is to compare the nature of the environmental variability benthic and pelagic animals experience in an estuarine tidal system. Here, benthic animals are considered as sessile animals living on the bottom in open waters and not influenced by factors such as desiccation or substrate composition. To achieve this, we carry out calculations on physicochemical and biological measurements made in the middle St. Lawrence Estuary to estimate the fluctuations in abiotic conditions animals experience on the horizontal and vertical axes in waters with different conditions of vertical stratification. In addition, we examine the effect of 3 patterns of vertical distribution commonly exhibited by pelagic estuarine animals (no vertical migrations, diel and tidal vertical migrations). Only tidal and daily fluctuations in abiotic conditions are examined. In contrast with sessile animals, pelagic animals can undertake longitudinal movements in the estuary which are associated with ontogenetic or seasonal migrations between different habitats (e.g. Laprise \& Dodson 1989b). Thus, long-term changes in abiotic conditions experienced by these animals cannot be interpreted only in terms of the intrinsic variability of the estuarine environment.

\section{STUDY AREA}

The study area was the middle St. Lawrence Estuary (Fig. 1), a large, drowned-river-valley estuary which receives an annual mean discharge of $10000 \mathrm{~m}^{3} \mathrm{~s}^{-1}$ from the river (D'Anglejan \& Smith 1973). The circulation is dominated by semi-diurnal, lunar tides (M2 type) ranging from 3 to $5 \mathrm{~m}$ in height. The results of a survey conducted from June 18 to 23,1987 , showed the characteristics of the permanent longitudinal gradients in salinity, temperature and concentration of suspended particulate matter (SPM) (Laprise \& Dodson 1989 b). Salinity averaged over the whole water column ranged from 0 upstream of Ile d'Orléans to over 30 downstream of Ile aux Coudres (Fig. 1). Temperature was negatively correlated with salinity (Pearson correlation: $\left.r^{2}=0.98, p<0.0001\right)$. Vertically averaged temperature varied from about $18^{\circ} \mathrm{C}$ upstream of 
Fig. 1. Middle St. Lawrence Estuary. Location of the stations sampled on June 18 to 23,1987 , and isolines of salinity (increments of 5) during high slack waters. Station numbers are consecutive from Stns 4 to 9 and Stns 24 to 28

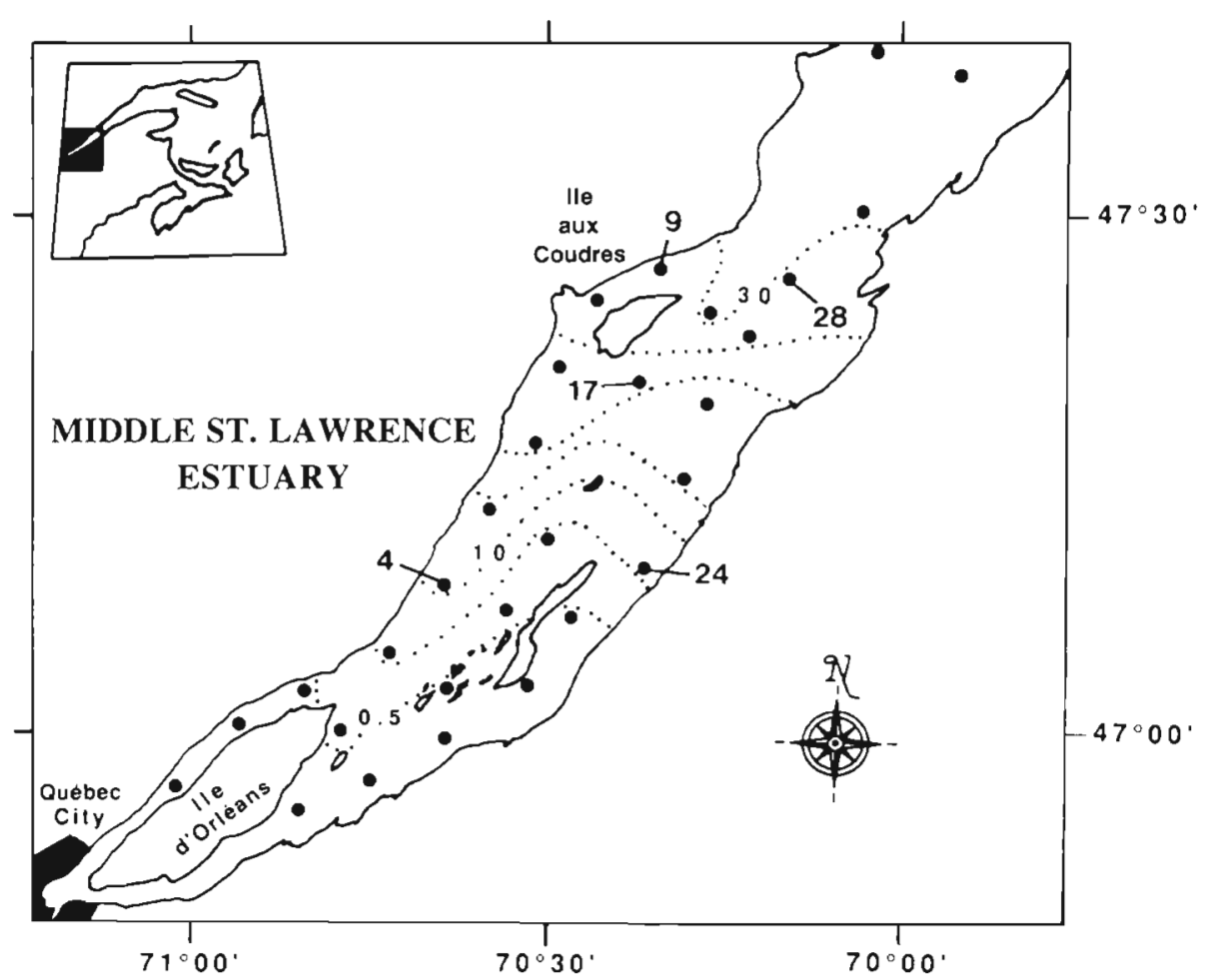

Tides were a major source of environmental variability in the estuary (Laprise \& Dodson 1989b). During the survey in June 1987, the longitudinal advection of water masses by tidal currents caused upstream and downstream movements of the estuarine environmental gradient. This is represented by the position of the salt-water intrusion, which was located approximately 9 to $10 \mathrm{~km}$ farther upstream during high slack waters compared to low slack waters. Temperature and SPM gradients were displaced according to the salinity gradient.

\section{MATERIALS AND METHODS}

We utilized the data from the survey conducted in the estuary in June 18 to 23,1987 , for our analysis. The sampling procedure is described in detail by Laprise $\&$ Dodson (1989b). Twenty-nine stations distributed in the 3 channels of the estuary were visited at low and high slack waters $( \pm 1$ h). At each station, ichthyoplankton and macrozooplankton were sampled and vertical measurements of salinity, temperature and SPM were carried out.

Environmental variability on the horizontal axis. To estimate the magnitude of the fluctuations in abiotic conditions benthic animals were exposed to during a tidal cycle in the estuary, we calculated the difference in near-bottom $(2 \mathrm{~m}$ at stations shallower than $25 \mathrm{~m}$ and $5 \mathrm{~m}$ at others $)$ salinity $\left(\Delta \mathrm{S}_{\mathrm{h}}\right)$, temperature $\left(\Delta \mathrm{T}_{\mathrm{h}}\right)$ and
SPM concentrations were typically greater nearer the bottom due to the negative buoyancy of SPM. 
SPM concentration $\left(\triangle \mathrm{SPM}_{\mathrm{h}}\right)$ between low and high slack water periods for each station.

In the case of pelagic animals, our approach consisted of comparing the distribution of a given population with respect to the environmental gradient for low and high slack waters. The differences in salinity $\left(\Delta S_{h}\right)$ or temperature $\left(\Delta \mathrm{T}_{\mathrm{h}}\right)$ in which the population is found at high and low slack waters give a measure of the fluctuations in these conditions an average individual in the population experiences during a tidal cycle.

Three species were used in our analysis: Atlantic tomcod Microgadus tomcod juveniles, of $43 \mathrm{~mm}$ ( $\pm 8 \mathrm{SD}$ ) average total length, the possum shrimp Neomysis americana, a planktonic mysid $<15 \mathrm{~mm}$ (Wigley \& Burns 1971), and rainbow smelt Osmerus mordax larvae, of $19 \mathrm{~mm}$ ( $\pm 3 \mathrm{SD}$ ) average total length. We chose these species because they exhibit different patterns of vertical distribution. Tomcod do not migrate vertically but remain in the deeper layers of the water column (Laprise \& Dodson 1990). Smelt larvae undertake tidal vertical migrations, moving to surface waters during floods and closer to the bottom during ebbs (Laprise \& Dodson 1989a). Although the vertical distribution of $N$. americana has not been investigated in the St. Lawrence Estuary, evidence suggests that this species undertakes diel vertical migrations (Hopkins 1965, Laprise \& Dodson unpubl. data). All these species were very abundant in the estuary and their populations were well contained in the area surveyed (Laprise \& Dodson 1989b, Laprise \& Dodson unpubl.)

Abundances of animals were related to the average salinity and temperature of the water column using regression analysis. Depth-integrated averages in salinity and temperature were calculated for each station as $\Sigma X_{i} / n$, where $x$ is the salinity (S) or the temperature $(T)$ at depth $i$, and $n$ is the number of depths sampled. Abundances were $\log$-transformed $[\log (a+1)]$ to homogenize the variance along the $x$-axis. Only samples coming from waters of salinities between 0.5 and 20 were included in the analysis. The salinity of 0.5 is considered to indicate the upstream limit of salt water penetration. In addition, 0.5 and 20 approximately correspond to the distribution limits of these species. The smallest order polynomial function was fitted so that residuals of the regression showed no significant trends along the $x$-axis. The distribution of the residuals of all regressions was not significantly different from a normal distribution (Shapiro-Wilk test, $p<0.05$; Shapiro \& Wilk 1965). Finally, regression lines at low and high slack waters were compared for each species using an analysis of covariance (Snedecor \& Cochran 1980). No satisfactory models could be found relating abundance and SPM concentrations, which precluded similar analyses.

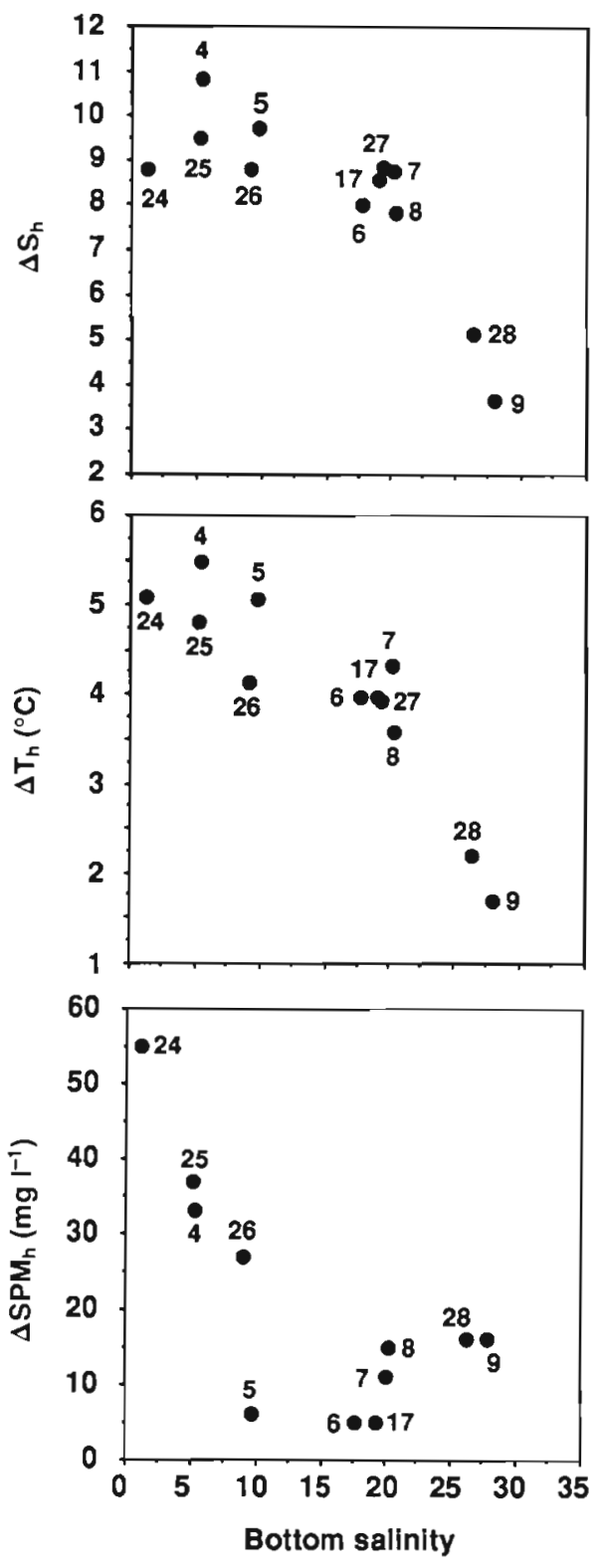

Fig. 2. Environmental variability on the horizontal axis for benthic animals in the middle St. Lawrence Estuary: difference in bottom salinity $\left(\Delta S_{h}\right)$, temperature $\left(\Delta T_{h}\right)$ and concentration of suspended particulate matter $\left(\Delta S P M_{h}\right)$ between low and high slack waters as a function of bottom salinity during low slack waters. Numbers indicate stations sampled on June 18 to 23,1987 (Fig. 1)

Environmental variability on the vertical axis. For each sample, the differences between bottom and surface salinities $\left(\Delta S_{v}\right)$, temperatures $\left(\Delta T_{v}\right)$ and SPM concentrations $\left(\triangle S P M_{v}\right)$ were calculated. These differences were then divided by the depth $z$ of the station, which results in a rate of change per meter of depth $\left(\Delta \mathrm{S}_{\mathrm{v}} / Z, \Delta \mathrm{T}_{\mathrm{v}} / z_{1} \Delta \mathrm{SPM}_{\mathrm{v}} / z\right)$. These ratios allow comparison of vertical variations in environmental conditions in water columns of different depths. The values of 
these ratios were plotted as a function of the average salinity of the water column, as this variable is a good predictor of animal distributions (see below). $\Delta S_{v} / Z$, $\Delta \mathrm{T}_{\mathrm{v}} / z$ and $\Delta \mathrm{SPM}_{\mathrm{v}} / z$ were multiplied by 10 to simulate the variability experienced by an animal migrating over $10 \mathrm{~m}$ in the water column, $10 \mathrm{~m}$ being the average depth of the largest, southern channel. These new indices were considered as $\Delta \mathrm{S}_{\mathrm{v} 10}, \Delta \mathrm{T}_{\mathrm{v} 10}$ and $\Delta \mathrm{SPM}_{\mathrm{v} 10}$.

Comparisons between axes and animals. Calculations were made in order to make the magnitude of the fluctuations in abiotic conditions experienced on both horizontal and vertical axis in the estuary more easily comparable among the different types of animals, $\Delta S_{h}$, $\Delta \mathrm{S}_{\mathrm{v} 10}, \Delta \mathrm{T}_{\mathrm{h}}, \Delta \mathrm{T}_{\mathrm{v} 10}, \Delta \mathrm{SPM}_{\mathrm{h}}$ and $\Delta \mathrm{SPM}_{\mathrm{v} 10}$ were divided by $0.5 t$ where $t$ is the period of the factor that generates the cyclic variability in abiotic conditions. For tidaland daily-related cycles, $t=12.25$ and $24 \mathrm{~h}$, respectively. As a result, we obtain a rate of change in abiotic conditions per hour $(\Delta \mathrm{S} / 0.5 t, \Delta \mathrm{T} / 0.5 t$ and $\Delta \mathrm{SPM} / 0.5 t)$ for all situations.

\section{RESULTS}

\section{Environmental variability on the horizontal axis}

The longitudinal, tidal displacement of water masses generated significant environmental fluctuations at one fixed location in the estuary (Fig. 2). For example, at $\operatorname{Stn} 4$, located upstream in the northern channel (Fig. 1), there were differences of $11,5.5^{\circ} \mathrm{C}$ and $33 \mathrm{mg}$ $\mathrm{l}^{-1}$ in bottom salinity, temperature and SPM concentration respectively between low and high slack waters. The magnitude of near-bottom environmental fluctuations in the estuary was maximum upstream and decreased downstream. At Stn 9, downstream of Ile aux Coudres, $\Delta \mathrm{S}_{\mathrm{h}}, \Delta \mathrm{T}_{\mathrm{h}}$ and $\Delta \mathrm{SPM}_{\mathrm{h}}$ were only $3.5,1.7^{\circ} \mathrm{C}$ and $16 \mathrm{mg} \mathrm{l}^{-1}$. The magnitude of tidal fluctuations in salinity and temperature followed a similar pattern in the estuary (Pearson correlation: $\left.r^{2}=0.93, p<0.0001\right) . \Delta S_{h}$ and $\Delta \mathrm{T}_{\mathrm{h}}$ diminished slowly upstream and decreased more rapidly downstream of lle aux Coudres. For stations with approximately the same bottom salinity at low slack water, the fluctuations in the most upstream section of the estuary were greater in the northern channel (Stns 4 \& 5) than in the southern channel (Stns 24, $25 \& 26$ ). In the case of SPM, large fluctuations in concentration were limited to the most upstream section of the estuary, just downstream of Ile d'Orléans in the northern channel (Stn 4) and Ile aux Oies in the southern channel
(Stns $24 \& 25$ ). In contrast to salinity and temperature, there were no definite cross-estuarine patterns in $\triangle \mathrm{SPM}_{\mathrm{h}}$. As a result, environmental variability experienced by sessile, benthic animals was maximum in the most upstream section of the estuary, and greater in the northern channel than in the southern channel.

The average salinity of the water column was a very good predictor of the abundances of pelagic animals in the estuary at both high and low slack waters (Table 1. Fig. 3). The logarithmic abundance of juvenile tomcod decreased linearly with increasing salinity whereas the abundances of Neomysis americana and smelt larvae formed a quadratic curve that reached a maximum around salinities of ca 4 to 5 and 8 to 10 , respectively.

The 3 pelagic species experienced small differences in salinity and temperature between low and high slack waters. Neomysis americana and smelt were found in salinities of ca 1.75 and 2.3 greater during low slack waters whereas tomcod was found in salinities of ca 1 greater during high slack waters (Fig. 3). In the case of temperature, N. americana and smelt were in ca 0.9 and $1.0^{\circ} \mathrm{C}$ less during low slack waters whereas tomcod was in temperatures ca $0.5^{\circ} \mathrm{C}$ higher during low slack waters (not shown). For all species, no statistical differences in variance, slope or elevation were detected between the regression lines at low and high slack waters by the analysis of covariance $(p>0.1)$. However, further analysis revealed that this test was not able to discriminate between similar curves of abundance when the difference in their position along the salinity axis was less than 3 due to the small number of samples. Nevertheless, these results demonstrate that tiderelated environmental variability was lower for pelagic animals than for benthic animals, indicating that their distribution moved upstream and downstream with tidal currents in a similar fashion to the environmental gradient.

Table 1. Middle St. Lawrence Estuary: regressions between the abundance (a) of Microgadus tomcod, Neomysis americana. Osmerus mordax and the average salinity $(\overline{\mathrm{S}})$ of the water column for low (LSW) and high (HSW) slack waters from June 18 to 23,1987

\begin{tabular}{|c|c|c|c|c|}
\hline Tide & $\mathrm{n}$ & Model & $r^{2}$ & $\mathrm{p}$ \\
\hline \multicolumn{5}{|c|}{ M. tomcod } \\
\hline LSW & 11 & $\log (a+1)=2.86-0.15 \overline{\mathrm{S}}$ & 0.88 & 0.0001 \\
\hline HSW & 9 & $\log (a+1)=2.95-0.14 \overline{\mathrm{S}}$ & 0.91 & 0.0001 \\
\hline \multicolumn{5}{|c|}{ N. americana } \\
\hline LSW & 11 & $\log (a+1)=3.90+0.212 \overline{\mathrm{S}}-0.019 \overline{\mathrm{S}}^{2}$ & 0.88 & 0.0002 \\
\hline HSW & 9 & $\log (a+1)=4.33+0.106 \overline{\mathrm{S}}-0.014 \overline{\mathrm{S}}^{2}$ & 0.89 & 0.0014 \\
\hline \multicolumn{5}{|c|}{ O. $\operatorname{mordax}$} \\
\hline LSW & 11 & $\log (a+1)=1.28+0.352 \overline{\mathrm{S}}-0.018 \overline{\mathrm{S}}^{2}$ & 0.53 & 0.0472 \\
\hline HSW & 9 & $\log (a+1)=2.17+0.204 \overline{\mathrm{S}}-0.013 \overline{\mathrm{S}}^{2}$ & 0.73 & 0.0198 \\
\hline
\end{tabular}



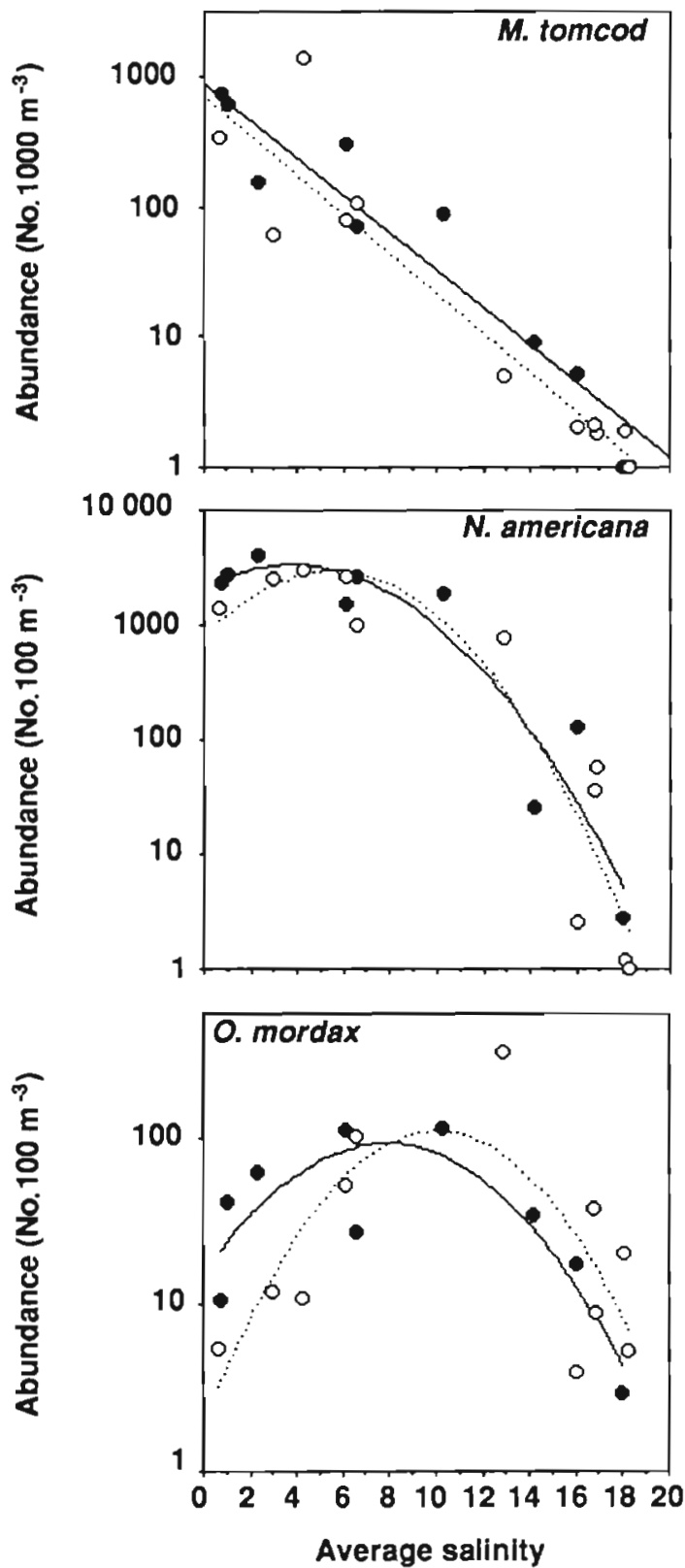

Fig. 3. Environmental variability on the horizontal axis for pelagic animals in the middle St. Lawrence Estuary: abundance of Microgadus tomcod, Neomysis americana and Osmerus mordax as a function of the average salinity of the water column at high $(\bullet)$ and low $(0)$ slack waters from June 18 to 23, 1987. Regression lines are illustrated for high (solid line) and low slack waters (dotted line). Regression coefficients are given in Table 1

\section{Environmental variability on the vertical axis}

At the time of our survey, the values of the ratios $\Delta \mathrm{S}_{\mathrm{v}} / z_{1} \Delta \mathrm{T}_{\mathrm{v}} / z$ and $\Delta \mathrm{SPM}_{v} / z$ varied significantly along the longitudinal salinity gradient (Fig. 4). The regression between $\Delta S_{v} / z$ and the average salinity of the water column shows that the rate of change in salinity over the water column was minimal in waters of lowest
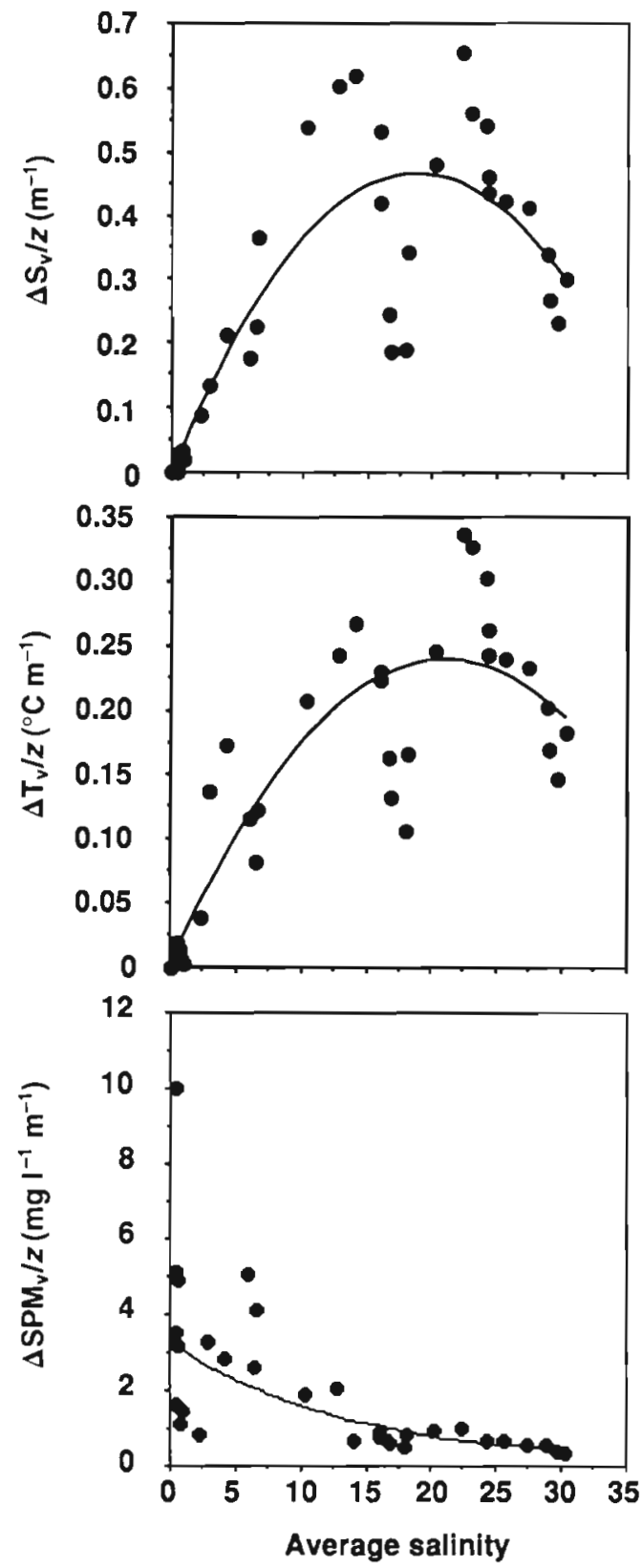

Fig. 4. Environmental variability on the vertical axis for pelagic animals in the middle St. Lawrence Estuary: vertical changes in salinity $\left(\Delta \mathrm{S}_{\mathrm{v}} / z\right)$, temperature $\left(\Delta \mathrm{T}_{\mathrm{v}} / z\right)$ and suspended particulate matter concentrations $\left(\Delta \mathrm{SPM}_{\gamma} / z\right)$ as a function of the average salinity $(\bar{S})$ of the water column from June 18 to 23,1987 . Models fitted: $\Delta \mathrm{S}_{v} / z=-0.0033+0.0500 \overline{\mathrm{S}}$ $-0.0013 \overline{\mathrm{S}}^{2}, \mathrm{r}^{2}=0.81, \mathrm{p}=0.0001 ; \Delta \mathrm{T}_{v} / z=0.0029+0.0226 \overline{\mathrm{S}}-$ $0.0005 \overline{\mathrm{S}}^{2}, \mathrm{r}^{2}=0.86, \mathrm{p}=0.0001 ; \Delta \mathrm{SPM}_{\mathrm{v}} / z=3.2413 \times 10^{-0.0304 \overline{\mathrm{S}}}$ $\mathrm{r}^{2}=0.65, \mathrm{p}=0.0001$

average salinities, corresponding to the well-mixed part of the estuary, and reached a maximum in waters of average salinity 19 . Then, the values of the ratio decreased rapidly as the average salinity of the water column increased and approached salinities typically found in the Gulf of St. Lawrence. The regression between $\Delta T_{v} / z$ and average salinity revealed the same 
longitudinal pattern of vertical stratification except that the maximum was reached in waters of average salinity 21. In the case of SPM, the largest differences between surface and bottom water concentrations were attained at the upstream limit of salt water intrusion. Then, $\triangle S P M_{v} / z$ decreases exponentially as a function of the average salinity of the water column, reaching minimum values in highest average salinities.

Given the longitudinal pattern of $\Delta \mathrm{S}_{v} / z, \Delta \mathrm{T}_{v} / z$ and $\triangle \mathrm{SPM}_{\mathrm{v}} / z$ in the estuary, animals migrating in the water column would experience maximum variability in salinity and temperature in average salinities around 20 , where a vertical displacement of $10 \mathrm{~m}$ would have generated a change in salinity and temperature of 4.7 and $2.4^{\circ} \mathrm{C}$. Animals would have experienced minimum fluctuations in salinity and temperature in the wellmixed part of the estuary, corresponding to average salinities less than 5 . Fluctuations would have been on the order of 0.33 and $0.25^{\circ} \mathrm{C}$ in an average salinity of 1 . In the case of SPM, maximum fluctuations in concentrations would have been experienced at the head of the estuary where a vertical migration of $10 \mathrm{~m}$ would have generated an average fluctuation of up to $30.2 \mathrm{mg}$ $\mathrm{l}^{-1}$, whereas fluctuations would have been only $3.9 \mathrm{mg}$ $\mathrm{l}^{-1}$ in an average salinity of 30 .

\section{Comparisons between axes and animals}

Tables $2 \& 3$ present the estimated hourly fluctuations in salinity, temperature and SPM concentration benthic and pelagic animals experienced in June 1987 on both horizontal and vertical axes at different locations in the St. Lawrence Estuary. Definite patterns of environmental variability emerge for the different types of animals. Variability in salinity and temperature experienced by pelagic animals undertaking vertical migrations is greater on the vertical axis than on the horizontal axis. Generally, benthic animals experience greater environmental variability than
Table 2. Environmental variability on the horizontal axis in the middle St. Lawrence Estuary: hourly changes in salinity $\left(\Delta S_{h}\right)$, temperature $\left(\Delta T_{h}\right)$ and concentration of suspended particulate matter $\left(\triangle S P M_{h}\right)$ experienced by benthic and pelagic animals during a tidal cycle (period $t=12.25 \mathrm{~h}$ )

\begin{tabular}{|lccc|}
\hline & $\begin{array}{c}\Delta \mathrm{S}_{\mathrm{h}} / 0.5 t \\
\left(\mathrm{~h}^{-1}\right)\end{array}$ & $\begin{array}{c}\Delta \mathrm{T}_{\mathrm{h}} / 0.5 t \\
\left({ }^{\circ} \mathrm{C} \mathrm{h}^{-1}\right)\end{array}$ & $\begin{array}{c}\Delta \mathrm{SPM}_{\mathrm{h}} / 0.5 t \\
\left(\mathrm{mg} \mathrm{l}^{-1} \mathrm{~h}^{-1}\right)\end{array}$ \\
\hline $\begin{array}{l}\text { Benthos } \\
\text { Upstream (Stn 4) }\end{array}$ & 1.80 & 0.90 & 5.4 \\
$\begin{array}{l}\text { Downstream (Stn 9) } \\
\text { Pelagos }\end{array}$ & 0.57 & 0.28 & 2.6 \\
$\begin{array}{l}\text { No vertical migrations } \\
\quad \text { Microgadus tomcod }\end{array}$ & 0.17 & 0.09 & - \\
$\begin{array}{c}\text { Diel migrations } \\
\text { Neomysis americana }\end{array}$ & 0.28 & 0.15 & - \\
$\begin{array}{c}\text { Tidal migrations } \\
\text { Osmerus mordax }\end{array}$ & 0.37 & 0.17 & - \\
\hline
\end{tabular}

pelagic animals everywhere in the estuary, even when migrations of pelagic animals in vertically stratified waters are considered. Variability in salinity and temperature for benthic animals is lowest in downstream parts of the estuarine gradient, whereas it is lowest in the most upstream part for pelagic animals. For both types of animals, variability in SPM concentrations is highest at the upstream end of the estuary. Finally, the pattern of vertical distribution of pelagic animals appears to affect the level of environmental variability they experience on both horizontal and vertical axes. Environmental variability is lowest in the case of nonmigrating animals whereas it is higher for animals undertaking diel vertical migrations and highest for those undertaking tidal vertical migrations.

\section{DISCUSSION}

Our results demonstrate that the nature of environmental variability experienced by benthic and pelagic animals in the St. Lawrence Estuary is different. For

Table 3. Environmental variability on the vertical axis in the middle St. Lawrence Estuary: hourly changes in salinity $\left(\Delta S_{v}\right)$, temperature $\left(\Delta T_{v}\right)$ and concentration of suspended particulate matter $\left(\Delta S M_{v}\right)$ experienced by pelagic animals during a vertical migration of $10 \mathrm{~m}$ at different locations along the salinity gradient. Diel migrations: $t=24 \mathrm{~h}$; tidal migrations: $t=12.25 \mathrm{~h}$

\begin{tabular}{|c|c|c|c|c|c|c|c|}
\hline \multirow{2}{*}{$\begin{array}{l}\text { Average } \\
\text { salinity }\end{array}$} & \multirow[b]{2}{*}{$t:$} & \multicolumn{2}{|c|}{$\Delta S_{v 10} / 0.5 t\left(h^{-1}\right)$} & \multicolumn{2}{|c|}{$\Delta \mathrm{T}_{\mathrm{v}, 0} / 0.5 t\left({ }^{\circ} \mathrm{C} \mathrm{h}^{-1}\right)$} & \multicolumn{2}{|c|}{$\Delta \mathrm{SPM}_{\mathrm{v} 10} / 0.5 t\left(\mathrm{mg} \mathrm{l}^{-1} \mathrm{~h}^{-1}\right)$} \\
\hline & & $12.25 \mathrm{~h}$ & $24 \mathrm{~h}$ & $12.25 \mathrm{~h}$ & $24 \mathrm{~h}$ & $12.25 \mathrm{~h}$ & $24 \mathrm{~h}$ \\
\hline 1 & & 0.05 & 0.03 & 0.04 & 0.02 & 4.9 & 2.5 \\
\hline 5 & & 0.35 & 0.18 & 0.17 & 0.09 & 3.7 & 1.9 \\
\hline 10 & & 0.59 & 0.30 & 0.29 & 0.15 & 2.6 & 1.3 \\
\hline 15 & & 0.73 & 0.37 & 0.36 & 0.18 & 1.8 & 0.9 \\
\hline 20 & & 0.76 & 0.39 & 0.39 & 0.20 & 1.3 & 0.7 \\
\hline 25 & & 0.68 & 0.35 & 0.38 & 0.20 & 0.9 & 0.5 \\
\hline 30 & & 0.49 & 0.25 & 0.32 & 0.16 & 0.6 & 0.3 \\
\hline
\end{tabular}


benthic, sessile animals, environmental variability is generated by the horizontal movement of the spatial gradients against the animals. In the St. Lawrence, tides are responsible for most of the short-term movements of the longitudinal gradients. The upstreamdownstream transport of water masses by tidal currents can create large fluctuations in physico-chemical conditions at a given location in the estuary, where the difference in bottom salinity between low and high slack waters can reach 11 . Consequently, environmental variability experienced by benthic animals in the St. Lawrence Estuary depends on the factors that influence the position of the longitudinal gradient, and the frequency of abiotic fluctuations depends on the periodicity of these factors.

In the case of pelagic animals, horizontal movements of spatial gradients in the estuary do not result in high short-term fluctuations in abiotic conditions. Animals should not move with respect to the horizontal gradients because they are passively transported upstream and downstream by currents in a similar fashion to the salinity gradient, allowing them to stay in stable physico-chemical conditions during a tidal cycle. However, due to the presence of vertical patterns in current speed and direction, net displacement of organisms along the estuarine gradient may be generated. Our results for tomcod, mysids and smelt suggest that the magnitude of the fluctuations experienced is a function of the vertical distribution of the animals in the water column. Tidal vertical migrations appear to generate the highest short-term variability, followed by diel migrations and non-migratory behaviour. Nonetheless, in all cases, the variability experienced on the horizontal axis remains very low compared to that experienced by benthic animals, the greatest difference measured for salinity between low and high slack waters being around 2 .

Vertical movement of animals against the vertical gradients appears to be the principal factor generating short-term environmental variability for pelagic species. Non-migrating species such as tomcod do not experience environmental variability on the vertical axis. However, species undertaking vertical migrations experience fluctuations in abiotic conditions and the magnitude of these fluctuations may be comparable to that experienced by benthic animals on the horizontal axis when waters are very stratified. For example, an animal migrating over 10 and $20 \mathrm{~m}$ in waters of salinity 19 would experience an average change in salinity of 4.7 and 9.4. However, in contrast to benthic animals, the level and the frequency of environmental variability experienced by pelagic animals are not controlled by some environmental factor but by the animals themselves, as the variability depends on their behaviour. For example, tidal migrations gener- ate higher variability than diel vertical migrations due to the higher frequency of the migrations.

The level and the nature of environmental variability experienced by benthic and pelagic animals in the St. Lawrence change with their position in the estuary. For benthic animals, fluctuations in salinity, temperature and SPM concentrations at a fixed location are greater at the upstream end of the estuary and in the northern channel. This is mainly related to the effect of the morphology of the estuary on water circulation. The funnel shape of the estuary concentrates tidal energy towards the upstream end (Ouellet \& Cerceau 1976). During the sampling period, tides ranged between 3.5 and $4.4 \mathrm{~m}$ at Québec City, at the upstream end of the estuary, and between 1.9 and $2.4 \mathrm{~m}$ at Pointe-au-Père, at the downstream end (Canadian tide and current tables). Consequently, longitudinal tidal displacements of water masses were greater towards the head of the estuary, causing greater fluctuations in environmental conditions at one fixed location. Tidal currents may also be faster in the deep and narrow northern channel, thus causing greater longitudinal displacement of the estuarine gradient than in the large and shallow southern channel

In the case of pelagic animals, fluctuations in salinity and temperature experienced on the vertical axis are minimum at the upstream end of the estuary, corresponding to the well-mixed waters of salinities less than 5, and maximum in the middle part of the longitudinal salinity gradient, in waters of average salinities around 20 . In contrast, maximum vertical fluctuations in SPM concentrations are experienced at the upstream end of the estuary, corresponding to the position of the maximum turbidity zone in well-mixed waters (D'Anglejan \& Smith 1973). The changes in abiotic conditions found in our study on the vertical axis are considered as maximum for the period studied because our sampling was conducted during slack waters. During ebbs and floods, tidal currents increase vertical mixing, which tends to homogenize salinity, temperature and SPM concentrations in the water column (Laprise \& Dodson 1989a).

In contrast to benthic animals, tides contribute to reducing the environmental variability for pelagic organisms. Tides provide most of the vertical mixing energy in the St. Lawrence. The longitudinal pattern of vertical stratification in salinity and temperature is partly related to the effect of the morphology of the estuary on water circulation, as greater vertical mixing of upstream waters is mostly due to tides of larger range and shallower depths (Ouellet \& Cerceau 1976).

Short-term fluctuations in salinity and temperature such as those observed in the St. Lawrence constitute obvious factors influencing the distribution of animals through their influence on physiology. However, we 
are not aware of studies on the effect of cyclic fluctuations of SPM concentrations on animals. Experience with constant concentrations of SPM suggests that the effect of fluctuations depends on the type of animal. Very high concentrations of SPM may be detrimental to benthic animals and fish (see reviews in Wilber 1971, Moore \& Moore 1976 and Bruton 1985). SPM clogs gills and feeding mechanisms of some filter feeders. Molluscs reduce pumping rates at high SPM concentrations. The presence of SPM in the water creates high turbidities which may reduce prey capture for visually feeding fishes as fast-swimming prey move more quickly out of the reduced visual field. On the other hand, relatively high concentrations of SPM may be advantageous for zooplankton and fish larvae. High turbidities may constitute a refuge from predation by large fishes (Bruton 1985). Turbidity values such as those found in the maximum turbidity zone may enhance feeding of fish larvae on small, slowly moving translucent organisms by increasing the contrast between the prey and the environment (Boehlert \& Morgan 1985, Breitburg 1988). Organic particles associated with the SPM constitute an important food source for detritivorous zooplankton and maximum turbidity zones are known as enhanced productivity areas for these organisms (Barclay \& Knight 1981, Zagursky \& Feller 1985, Dodson et al. 1989). This suggests that fluctuation in SPM concentrations is potentially an important factor in the distribution of fish and benthic animals as it may affect their feeding activities, whereas it may not be detrimental in the case of zooplankton and fish larvae.

The different nature of environmental variability experienced by pelagic and benthic animals in the St. Lawrence Estuary suggests that some aspects of hypotheses based on the assumption of environmental variability should be reconsidered in the case of pelagic animals. For example, the low diversity of estuarine animals is often associated with the abiotic variability of the environment. If such is the case, our results predict that the minimum number of species for both types of animals should be reached at different locations in the estuary. While the number of benthic species should be minimum at the upstream end of the estuary, the minimum number of pelagic species should be found in waters with average salinities of around 20 .

The results of studies on benthic and pelagic fauna in the St. Lawrence Estuary are consistent with these predictions. In a study on the longitudinal distribution of the epibenthic fauna, Ardisson \& Bourget (1992) found that the species richness of the sessile species diminishes steadily following the decreasing salinity gradient. Fourteen species were found in the lower part of the estuary during the period between 1975 and
1985 whereas only 8 species were found in the upstream part of the estuary. Their sampling consisted in collecting animals on suspended navigation buoys moored in open coastal waters within the surface 0 to $2 \mathrm{~m}$ depth layer. This procedure eliminated factors influencing the distribution of epibenthic animals such as the inshore tidal emersion-immersion cycle and the substrate composition. As such, the observed pattern in species richness may be mostly attributed to the circulation and the physico-chemical characteristics of the water column

In the case of pelagic animals, waters of salinities around 20 appear to constitute a major discontinuity in the distribution of zooplankton and ichthyoplankton in the middle St. Lawrence Estuary. Two distinct communities of zooplankton species are present in the estuary (Bousfield et al. 1975, Dodson et al. 1989). A first community is associated with the upstream wellmixed waters corresponding to the maximum turbidity zone, and a second community is associated with the most saline waters downstream of lle aux Coudres. Abundances of zooplankton in the middle part of the salinity gradient are depressed and plankton in this area consists mostly of drifting, non-reproducing individuals. No species population center is associated with the most vertically stratified waters (Laprise \& Dodson unpubl.). The same pattern of distribution was found for ichthyoplankton. Larvae of 2 fish species, rainbow smelt and Atlantic tomcod, are most abundant in salinities less than 15 (Laprise \& Dodson 1989b), whereas herring larvae Clupea harengus are found in the very saline waters downstream of Ile aux Coudres (Henri et al. 1985, Fortier \& Gagné 1990). Thus, in contrast to benthic animals, zooplankton and fish larvae in the middle St. Lawrence Estuary appear to be associated with the most vertically mixed parts of the estuary.

We propose that environmental variability on the vertical plane is an important factor in understanding the distribution of pelagic animals in estuaries because of the constraint imposed by estuarine circulation on the retention of these animals. In fact, it appears that planktonic animals must undertake vertical migrations in order to achieve retention at intermediate positions along the longitudinal estuarine gradient. In positive estuaries, where river discharge and precipitation are greater than evaporation, there is generally a residual upstream displacement of salt waters near the bottom that compensates the downstream flow of fresh waters at the surface (Emery \& Stevenson 1957). As a result, animals that remain in surface waters are transported downstream (e.g. Fortier \& Leggett 1982) whereas individuals that remain in deep waters accumulate at the head of the estuary (e.g. Laprise \& Dodson 1989b). The principal mechanism allowing animals to remain 
at intermediate positions in the estuary is vertical migration in the vertical shear of current speed and direction. Consequently, well-mixed parts of estuaries should be considered as abiotically stable habitats for the pelagic fauna, whereas vertically stratified areas should be considered as abiotically variable except in the case of hydrodynamic systems where vertical migrations are not necessary for the retention of animals.

Acknowledgements. We thank Drs Pierre Pepin and Peter Shelton and an anonymous referee for their useful comments on the manuscript. This project was supported by grants from FCAR (Québec) and NSERC (Canada) to J.J.D. and Groupe Interuniversitaire de Recherches Océanographiques du Québec. R.L. was funded by a Department of Fisheries and Oceans visiting fellowship.

\section{LITERATURE CITED}

Ardisson, P.-L., Bourget, E. (1992). Large-scale ecological patterns: discontinuous distribution of marine benthic epifauna. Mar. Ecol. Prog. Ser. 83: 15-34

Barclay, W. R., Knight, A. W. (1981). The nutritional significance of the distribution of suspended particulate material in the upper San Francisco Bay estuary. In: Cross, R. D., Williams, D. L. (eds.) Proceedings of the national symposium on freshwater inflow to estuaries, Vol. 1. FWS/OBS81/04. U.S. Department of the Interior, Washington, DC, p. $55-70$

Bassindale, R. (1943). A comparison of the varying salinity conditions of the Tees and Severn estuaries. J. Anim. Ecol. 12: $1-10$

Beadle, L. C. (1972). Physiological problems for animal life in estuaries. In: Barnes, R. S. K., Green, J. (eds.) The estuarine environment. Applied Science Publishers, London, p. 51-60

Boehlert, G. W., Morgan, J. B. (1985). Turbidity enhances feeding abilities of larval Pacific herring. Clupea harengus pallasi. Hydrobiologia 123: 161-170

Bousfield, E. L., Filteau, G., O'Neil, M., Gentes, P. (1975). Population dynamics of zooplankton in the middle St. Lawrence Estuary. In: Cronin, L. E. (ed.) Estuarine research, Vol. 1. Academic Press, New York, p. 325-351

Breitburg, D. L. (1988). Effects of turbidity on prey consumption by striped bass larvae. Trans. Am. Fish. Soc. 117 : $72-77$

Bruton, M. N. (1985). The effects of suspensoids on fish. Hydrobiologia 125: 221-241

D'Anglejan, B., Smith, E. C. (1973). Distribution, transportation and composition of suspended matter in the St. Lawrence Estuary. Can. J. Earth Sci. 10: 1380-1396

De Jonge, V. N. (1974). Classification of brackish coastal inland waters. Hydrobiol. Bull. 8: 29-39

Dodson, J. J., Dauvin, J.-C., Ingram, R. G., D'Anglejan, B. (1989). Abundance of larval rainbow smelt (Osmerus mordax\} in relation to the maximum turbidity zone and associated macroplankton fauna of the Middle St. Lawrence Estuary. Estuaries 21: 66-81

Emery, K. O., Stevenson, R. E. (1957). Estuaries and lagoons. Mem. geol. Soc. Am. 67: 673-693

Fortier, L., Gagné, J. A. (1990). Larval herring (Clupea haren- gus) dispersion, growth, and survival in the St. Lawrence Estuary: match/mismatch or membership/vagrancy? Can. J. Fish. Aquat. Sci. 47: 1898-1912

Fortier, L., Leggett, W. C. (1982). Fickian transport and the dispersal of fish larvae in estuaries. Can. J. Fish Aquat. Sci. 39: 1150-1163

Gagnon, M., Lacroix, G. (1981). Zooplankton sample variability in a tidal estuary: an interpretative model. Limnol. Oceanogr. 26: 401-413

Gagnon, M., Lacroix, G. (1982). The effects of tidal advection and mixing on the statistical dispersion of zooplankton. J. exp. mar. Biol. Ecol. 56: 9-22

Green, J. (1968). The biology of estuarine animals. University of Washington, Seattle

Haedrich, R. L. (1982). Estuarine fishes. In: Ketchum, B. H. (ed.) Ecosystems of the world, Vol. 26, Estuaries and enclosed seas. Elsevier Scientific Publishing Company, Amsterdam, p. 183-202

Heerebout, G. R. (1970). A classification system for isolated brackish inland waters, based on median chlorinity and chlorinity fluctuation. Neth. J. Sea Res. 4: 494-503

Henri, M., Dodson, J. J., Powles, H. (1985). Spatial configurations of young herring (Clupea harengus harengus) larvae in the St. Lawrence Estuary: importance of biological and physical factors. Can. J. Fish. Aquat. Sci. 42: 91-104

Holliday, F. G. T. (1971). Salinity: fishes. In: Kinne, O. (ed.) Marine ecology, Vol. 1. Part 2. Wiley-Interscience, London, p. 997-1033

Hopkins, T. L. (1965). Mysid shrimp abundance in surface waters of Indian River inlet, Delaware. Chesapeake Sci. 6: $86-91$

Kinne, O. (1971). Salinity: invertebrates. In: Kinne, O. (ed.) Marine ecology, Vol. 1, Part 2. Wiley-Interscience, London, p. 821-996

Laprise, R., Dodson, J. J. (1989a). Ontogeny and importance of tidal vertical migrations in the retention of larval smelt Osmerus mordax in a well-mixed estuary. Mar. Ecol. Prog. Ser. 55: 101-111

Laprise, R., Dodson, J. J. (1989b). Ontogenetic changes in the longitudinal distribution of two species of larval fish in a turbid well-mixed estuary. J. Fish Biol. 35 (Suppl. A): $39-47$

Laprise, R., Dodson, J. J. (1990). The mechanism of retention of pelagic tomcod, Microgadus tomcod, larvae and juveniles in the well-mixed part of the St. Lawrence Estuary. Environ. Biol. Fish. 29: 293-302

McLusky, D. S. (1968). Some effects of salinity on the distribution and abundance of Corophium volutator in the Ythan estuary. J. mar. biol. Ass. U.K. 48: 443-454

McLusky, D. S. (1981). The estuarine ecosystem. John Wiley \& Sons, New York

Miller, C. B. (1970). Some environmental consequences of vertical migration in marine zooplankton. Limnol. Oceanogr. 15: 727-741

Miller, J. M., Crowder, L. B., Moser, M. L. (1985). Migration and utilization of estuarine nurseries by juvenile fishes: an evolutionary perspective. Contr. mar. Sci. 27: 338-352

Moore, J. W., Moore, T. A. (1976). The basis of food selection in flounders, Platichythus flesus (L.), in the Severn Estuary. J. Fish Biol. 9: 139-156

Ouellet, Y., Cerceau, J. (1976). Mélange des eaux douces et des eaux salées du Saint-Laurent, circulation et salinité. Les Cahiers de Centreau 1(4): 1-57

Parry, G. (1966). Osmotic adaptation in fishes. Biol. Rev. 41. $392-444$

Pritchard, D. W. (1967). What is an estuary: physical view point. In: Lauff, G. H. (ed.) Estuaries. The Horn-Shafer 


\section{Company, Baltimore, p. 3-5}

Remane, A., Schlieper, C. (1971). Biology of brackish water. Wiley Interscience, New York

Sanders, H. L. (1969). Benthic marine diversity and the stability-time hypothesis. Brookhaven Symp. Biol. 22: $71-81$

Shapiro, S. S., Wilk, M. B. (1965). An analysis of variance test for normality (complete samples). Biometrika 52: 591-611 Snedecor, G. W., Cochran, W. G. (1980). Statistical methods, 7 th edn. The Iowa State University Press, Ames

Vernberg, W. B., Vernberg, F. J. (1972). Environmental phys-

This article was submitted to the editor iology of marine animals. Springer-Verlag, New York

Wigley, R. L., Burns, B. R. (1971). Distribution and biology of mysids (Crustacea, Mysidacea) from the Atlantic Coast of the United States in the NMFS Woods Hole collection. Fish. Bull. U.S. 69: 717-746

Wilber, C. G. (1971). Turbidity: animals. In: Kinne, O. (ed.) Marine ecology, Vol. 1, Part 2. Wiley-Interscience, London, p. 1182-1189

Zagursky, G., Feller, R. J. (1985). Macrophyte detritus in the winter diet of the estuarine mysid. Neomysis americana. Estuaries 8: 355-362

Manuscript first received: July 29, 1992

Revised version accepted: February 5, 1993 